were ripe for inclusion, and those that are still rather undeveloped. The most obvious of the first kind are the pharmacology of the alimentary tract, the uterus, the bronchi and the eye. A great deal is known about methods of investigating these in man. Less developed subjects include the clinical pharmacology of the skin, the ear and nose, and the action of drugs in infants and children. A third volume would therefore be most welcome.

This is a very useful book for everyone interested in the study of drugs in man. It is a book to possess, not just to consult in the library.

A. HeRXheimer

\section{PREVENTING DISEASE}

\section{Foundations of Immunochemistry}

By Eugene D. Day. Pp. xiv +209. (Baltimore, Md.: The Williams and Wilkins Cormpany, 1966. Distributed in the United Kingdom by E. and S. Livingstone, Ltd., Edinburgh.) $68 s$.

Professor DAy has made a very successful attempt at relating the activity of antibody to its structure, rather than the reverse. By applying modern views on the structure of proteins, particularly immunoglobulins, to a reappraisal of earlier work, he secures a firm foundation for further building, with a surer understanding of the principles involved.

It is inevitable that no book dealing with a rapidly growing subject can be completely up to date, and the very recent discoveries on the nature of the $N$-terminal ends of the polypeptide chains of immunoglobulins will probably cause some modifications in the author's tentatively expressed views on the sequence of steps in the biosynthesis of antibody. Nevertheless, his original approach to the subject is extremely stimulating, and the book will undoubtedly be acclaimed by all interested in immunochemistry.

The application of phase diagrams to protein-antiprotein serological interactions leads to some interosting views on the mechanism of the precipitin reaction and a reinterpretation of much earlier work. Many of the confusions arising from earlier work are also resolved or brought into better perspective by the author's clear and critical approach to the subject.

The coverage is very thorough, leading from a consideration of the physical chemistry of serum, through the structure of antibodies to their reactions with haptens and full antigens, and the effects on these reactions of chemical modification of antigen or antibody. The last two chapters are devoted to a critical consideration of antibody purification methods and the nature of antigenicity.

In several cases the relationship between the figures, their legends, and the general text is somewhat lacking in clarity, and no attempt has been made to consider the genetic implications of antibody structure and hoterogeneity, but these are minor faults in an otherwise excellent book, which one hopes will be corrected in later editions.

G. E. Francis

\section{LOOKING FOR A CURE}

\section{Anticancer Agents}

By Frances F. Knock. (A Monograph in the Bannerstone Division of American Lectures in Living Chemistry.) Pp. xix + 272. (Springfield, Illinois: Charles C. Thomas, 1967.) $\$ 15.50$.

DR. KNock would seem to be admirably equipped to write a book on the wide aspocts of cancer treatment. She was originally an organic chemist trained by Dr. Morris Kharasch in Chicago and is both a surgoon and a physician in the United States. In this book she considers almost all the means which are available for the treatment of cancer in man, including surgery, radiotherapy, chemotherapy and the immunological attack. The treatment of cancer and other diseases by new drugs raises ethical problems and these are discussed by Dr. Knock.

During the five years after the Second World War there appeared to be rapid progress in chemotherapy, but since then the rate of progress has been slower but continuous. Many drugs established as anti-cancer agents are considered. Most of these are either alkylating agents that can be considered as nitrogen mustard derivatives, anti-metabolites that are antagonists of amino-acids, folic acid, purines or pyrimidines, steroid hormones and antihormones, antibiotics and alkaloids. There is also a miscellaneous group of compounds which includes methylhydrazine derivatives, urethane and hydroxyurea. The problem of deciding which drug or clinical procedure should be used for any particular patient requires knowledge and consideration.

One group of substances which are considered in this book are the sulphydryl inhibitors that may inhibit enzyme systems concerned with repair after treatment by radiation or radiomimetic substances. These inhibitors would seem to deserve particular attention.

The problem of treatment of cancer involves a full understanding of chemical and physical processes and also involves understanding the patient. One of the difficulties with cancer is that each case appears to be unique, but it is hoped that these difficulties will be understood and possibly made use of in successful treatment of the disease. Dr. Knock considers briefly the causes of cancer, the abolition of which should lead to the prevention of cancer; both the treatment and prevention require energetic investigation.

This book, which is very wide in its approach, should be useful to clinicians concerned in the treatment of cancer patients and to workers who are entering the field of cancer research.

E. Boyland

\section{AFRICAN BIRDS IN DEPTH}

\section{The Bird Faunas of Africa and Its Islands}

By R. E. Moreau. Pp. viii +424 . (London: Academic Press, Inc. (London), Ltd.; New York: Academic Press, Inc., 1966.) $100 s$. $\$ 18$.

THE author of this book is a distinguished ornithologist who has spent much of his life in two strongly contrasted parts of Africa, also visiting others; and he has devoted many years to assembling the mass of data here ably deployed and discussed. The book is an authoritative scientific contribution, but not one only for specialists, for there is much in it that many biologists and naturalists should find of interest, with implications extending to other taxa and other continents.

The study is both geographical and ecological, and the author has taken full account of the known changes in climate and habitat during the Pleistocene. He has applied two main criteria to the bird faunas of different areas-the number of native species, and the extent to which these are endemic. The incidence of breeding seasons is another important consideration.

The work covers the whole of Africa and the islands include Madagascar. An account of the various environments is presented in terms of physical features, climate and vegetation. Much of the geographical distribution of birds is explicable on this basis alone, but many puzzles remain and the discontinuous distribution of certain species has to be considered in the light of climatic vicissitudes during the past 20,000 years. Characteristic of the African tropies are tho apparently isolated montane populations of idontical forms; because recognizable subspeciation can occur within a hundred generations, it seems likely that some of the gaps are traversed more regularly than has boon supposod. 